ISSN 2179-6750

\title{
Análise de boas práticas de manipulação em cozinhas escolares
}

\author{
Bianca Simões da Silva, Wanessa Françoise da Silva Aquino Carmo
}

\section{Resumo}

Há um grande risco provido do consumo de alimentos contaminados por micro-organismos patogênicos, podendo levar o indivíduo a um estado patológico, variando de leve desconforto a reações intensas e até mesmo à morte, principalmente nos grupos mais suscetíveis, como as crianças e idosos. Com isso, a preocupação com a qualidade nos serviços de alimentação torna-se mais relevante quando se refere à alimentação escolar. Os objetivos deste estudo são avaliar os aspectos higiênico-sanitários de Unidades de Alimentação e Nutrição Escolares de escolas estaduais e analisar o entendimento sobre Boas Práticas das cozinheiras. Foi feita aplicação de questionário contendo perguntas diretas e tópicos relativos à higienização das instalações, equipamentos e utensílios; ao controle e garantia de qualidade do alimento preparado; ao controle da higiene e saúde dos manipuladores; ao manejo de resíduos e controle integrado de vetores e pragas urbanas às cinco escolas estaduais e uma municipal do município, localizado no interior de Minas Gerais, na região da zona da mata mineira e uma visita às dependências das cozinhas e estoques para observações dos locais. Constatou-se que as cinco escolas estaduais não possuem nutricionista atuante, $50 \%$ das cozinheiras não possuem treinamento em Boas práticas de Higiene, $83 \%$ fazem a sanitização de alimentos de forma incorreta. Grande parte das cozinheiras de escolas não têm o devido entendimento e treinamento para que se garanta uma boa qualidade e segurança no preparo de alimentos, devido à falta do profissional nutricionista atuando para que se garantam tais requisitos.

Descritores: Alimentação Escolar; Higiene dos Alimentos 